\title{
Public Perception on Quarantine During the COVID-19 Outbreak in Bangladesh: A Community Survey-Based Study
}

\author{
Riyan Al Islam Reshad ${ }^{1}$ (D), Asir Newaz Khan 2 (D), Tawfiq Alam Jishan ${ }^{1}$ (D),
} Mowaz Mohammed Abdul Karim ${ }^{3}$ (D), Md. Faruque Miah ${ }^{1^{*}}$ (D)

${ }^{1}$ Department of Genetic Engineering and Biotechnology, Shahjalal University of Science and Technology, Sylhet, Bangladesh

${ }^{2}$ Department of Economics and Social Sciences, BRAC University, Bangladesh

${ }^{3}$ Department of Civil and Environmental Engineering, Shahjalal University of Science and Technology, Sylhet, Bangladesh

\section{Correspondence:}

Md. Faruque Miah

Address: Department of Genetic Engineering and Biotechnology, Shahjalal University of Science and Technology, Sylhet, Bangladesh

Email: faruque-btc@sust.edu
Received: 13.10.2021,

Accepted: 25.12.2021

https://doi.org/10.29333/jcei/11703

\begin{abstract}
Backgrounds: The usage of quarantine emphasizes the complex interaction between the human rights of the citizen and the collective rights of the community. Therefore, the public's views and expectations about quarantine to prevent the transmission of COVID-19 were explored in this report.
\end{abstract}

Results: The findings of this study show widespread public support for the use of quarantine and legal sanctions for those who do not comply with the regulations. However, this assistance is conditional on applying regulatory provisions to prevent improper usage and the offering of psychosocial support to those impacted.

Conclusions: When quarantine cannot be implemented, public health policymakers and government leaders can introduce a robust service scheme. They can implement a comprehensive infrastructure of psychosocial care to protect, instruct, and educate frontline public health staff. The public can also be invited to participate in an open discussion about the ethical efficacy of restrictive principles during this COVID-19 pandemic.

Keywords: COVID-19, public perception, quarantine

\section{INTRODUCTION}

Quarantine is one of the oldest methods of controlling the outbreak of any infectious diseases, especially those for which vaccines or other therapeutics are not available. Different countries have faced several quarantine events in the $21^{\text {st }}$ century to prevent the transmission of various infectious diseases, including the mass quarantine event for the most recent severe acute respiratory syndrome coronavirus 2 (SARS-CoV-2) outbreak in most of the countries of the world from 2020 [1,2]. This restrictive measure was successful in terminating the outbreaks and reducing the death rate of a range of infectious diseases, including the dated Spanish flu pandemic (1918) and recent SARS-CoV (2001) outbreak in the past $[3,4]$. However, although the isolation, which is the restrictive measure of an asymptomatic individual, is more palpable, quarantining the individuals at high risks of being infected is more controversial regarding ethics and legality [5-7]. A high degree of compliance to the response of quarantine enforcement during different viral disease outbreaks was reported among the people of high-income countries, i.e., the USA and Canada $[8,9]$. Nevertheless, the public perception varies from one ethnic group and even one nation to another as evidenced by the response of people of South Korea during the middle east respiratory syndrome coronavirus (MERS-CoV) outbreak in $2015[10,11]$. People from low and middle-income countries like Bangladesh, a country with a dense population of more than 164 million people, might have different perspectives on quarantine enforcement to control the spread of coronavirus disease 2019 (COVID-19).

Bangladesh recorded the first death from COVID-19 on March 18, 2020, after 
confirming the first infected case on March 08, 2020 [12,13]. However, people's maintenance depends on different factors, i.e., knowledge, financial stability, willingness, etc. For example, maintaining the quarantine is akin to economic suicide for people like farmers, rickshaw pullers, tea stallers, and slum dwellers who need to struggle for bread and butter every day. Again, the lack of knowledge of people about quarantine imposes a further challenge to maintain it appropriately, as evident by different families who were found to utilize the quarantine opportunity as family vacation $[14,15]$. On the contrary, financially stable people and have proper knowledge are more likely to maintain the quarantine order. Thus, the perception of quarantine varies from one group of people to another. Consequently, because of both potential adverse effects and the necessity of quarantine, it is essential to comprehend how it is viewed among different groups of people to recommend further necessary steps.

In this study, observation is tried to explore the public perception of the use of quarantine to prevent the spread of COVID-19. The scientific findings of this study will help to understand the necessity of quarantine use following the further steps, which might be required for its proper maintenance.

\section{MATERIALS AND METHODS}

\section{Participants and Setting}

The study was conducted in multiple regions of different districts in Bangladesh. Bangladesh is a densely populated country of South Asia with more than 164 million people and a population density of 1,115.62 people per square kilometer. The surface area in Bangladesh is currently at 147,570 square kilometers (or 56,977 square miles). The country has 64 districts, and among these, the capital city Dhaka is the largest and most populated city with almost 14.4 million people and a density of 19,447 people per square kilometer [1].

All the participants provided consent before the survey. Age or sex stratification was not applied in this study. The approval of research ethics was obtained from the institutional ethical committee, Shahjalal University of Science and Technology, Sylhet, Bangladesh.

\section{Survey Utensil}

The survey questionnaire was taken and adapted from a prior study carried out by Shawn et al. in 2005 after the SARS-CoV outbreak in Canada. The questionnaire contained 14 items designed precisely to measure the public perceptions of the enforced quarantine to prevent COVID19 in Bangladesh. The items were selected to cover various topics, including the legitimacy of quarantine, the supposed efficacy of the restrictive policy, and the assistance offered to those affected by quarantine compliance. The participants were asked to indicate their degree of agreement or disagreement with each questionnaire item. The response format was a 5-point Like-art style template, with options like (1) strongly agree, (2) somewhat agree, (3) neutral, (4) somewhat disagree, and (5) strongly disagree, and so on.

At first, the participants were asked to provide demographic information such as age, location, marital status, residence, ethnicity, education, occupation, and religion. Then, all participants were informed that the inquiry would be used for academic/research purposes and, after that, introduced with the standard definition of quarantine

"Quarantine is the prohibition of normal movement of people to avoid the transmission of an infectious disease."

and infectious disease

"Infectious diseases are the diseases
which transmit from one person to
another or animal to person through
airborne bacteria, viruses or any bodily
fluid of infected person."

\section{Data Collection and Analysis}

A total of 50 interviewers collected data from different regions of Bangladesh between January 04, 2021, and February 18, 2021, with the aid of project supervisors. The data were collected using an online survey strategy by providing the respondent with the link to a formulated Google form containing the questionnaire. Few data were also collected using the online computer-assisted telephone interviewing (CATI) strategy from the interviewers' friends, neighbors, and relatives.

Inclusion criteria included a minimum of 18 years or more of the age of the participants and eligibility to provide consent for the survey. All the participants confirmed their eligibility (18 years of age or more) to consent before participating in the survey.

\section{Ethical Statement}

The study methodology was approved by SUST internal ethical committee (Reference ID: IEC-101(1)/003). For participating in this study, no monetary compensation was offered.

\section{RESULTS}

The interviewers invited 1,758 adults, both male, and female, to participate in the interview, and 1,526 responded. Questionnaires from 48 participants were omitted because they were incomplete. Therefore, the final review of the study included data from 1,748 adult male and female participants, with an overall response rate of $86.8 \%$. The personal and demographic information of the participants is shown in (Table 1 and Table 2). About half of the participants (46.9\%) were between 18 and 25 , with just $0.59 \%$ being over 60 . The sample pool included people from all lifestyles and came from all eight divisions of Bangladesh. 
Public Perception on Quarantine during the COVID-19 Outbreak in Bangladesh

Table 1. Personal characteristics and quarantine status

\begin{tabular}{|c|c|c|c|}
\hline & \multicolumn{2}{|c|}{ Gender } & \multirow[t]{2}{*}{ Total } \\
\hline & Female & Male & \\
\hline \multicolumn{4}{|l|}{ Personal Characteristics } \\
\hline \multicolumn{4}{|l|}{ Age Group } \\
\hline $18-25$ & 235 & 458 & 693 \\
\hline $26-40$ & 223 & 413 & 636 \\
\hline $41-60$ & 50 & 91 & 141 \\
\hline Above 60 & 0 & 8 & 8 \\
\hline Total & 508 & 970 & 1,478 \\
\hline \multicolumn{4}{|l|}{ Location } \\
\hline Dhaka & 252 & 477 & 729 \\
\hline Chittagong & 81 & 172 & 253 \\
\hline Rajshahi & 29 & 68 & 97 \\
\hline Sylhet & 59 & 78 & 137 \\
\hline Barisal & 22 & 44 & 66 \\
\hline Khulna & 18 & 50 & 68 \\
\hline Rangpur & 24 & 45 & 69 \\
\hline Mymensingh & 24 & 45 & 69 \\
\hline Total & 508 & 970 & 1,478 \\
\hline \multicolumn{4}{|c|}{$\begin{array}{l}\text { Quarantine Status } \\
\text { Is/Was anyone in your family home quarantined? }\end{array}$} \\
\hline No & 370 & 733 & 1,103 \\
\hline $\begin{array}{l}\text { Yes, myself but nobody else } \\
\text { in my home }\end{array}$ & 32 & 39 & 71 \\
\hline $\begin{array}{l}\text { Yes, myself and someone } \\
\text { else in my home }\end{array}$ & 72 & 157 & 229 \\
\hline $\begin{array}{l}\text { Yes, not myself but someone } \\
\text { else in my home }\end{array}$ & 34 & 41 & 75 \\
\hline Total & 508 & 970 & 1,478 \\
\hline
\end{tabular}

About $65 \%$ of the participants $(67.7 \%)$ had completed high school or higher education, with $16.84 \%$ attending university. $41.6 \%$ were students, $20.8 \%$ were self-employed, and the remaining $37.6 \%$ were unemployed, homemakers, service holders, or involved in the business. Furthermore, $53 \%(52.97 \%)$ respondents were single (i.e., unmarried or divorced). In terms of religious affiliation, over $80 \%(82.68 \%)$ of participants were Muslims. Over 90\% (93.84\%) of participants were born Bangladeshi, and $~ 60 \%$ (59.20\%) of the respondents were dwellers of urban areas.

The results of the 14 survey items (ranging from "strongly agree" to "strongly disagree") are shown in Table 2. The majority of respondents said they "strongly agree" or "somewhat agree" to each item. According to the results, $88 \%$ of respondents believed that quarantine is an effective way to reduce the transmission of this outbreak and that the government should implement it. During outbreaks, authorities should be able to order people to be quarantined. Furthermore, $76 \%$ of respondents supported that the authority's quarantine orders should be enforced at all costs.
Table 2. Sociodemographic characteristics of participants

\begin{tabular}{|c|c|}
\hline Variables & Value $(n=1,478)$ \\
\hline \multicolumn{2}{|l|}{ Marital Status (\%) } \\
\hline Unmarried & $50.47 \%$ \\
\hline Married & $47.02 \%$ \\
\hline Divorced & $2.51 \%$ \\
\hline \multicolumn{2}{|l|}{ Residence (\%) } \\
\hline Rural & $40.8 \%$ \\
\hline Urban & $59.2 \%$ \\
\hline \multicolumn{2}{|l|}{ Ethnicity (\%) } \\
\hline By Born Bangladeshi & $93.84 \%$ \\
\hline Tribal & $6.16 \%$ \\
\hline \multicolumn{2}{|l|}{ Education (\%) } \\
\hline Uneducated & $4.46 \%$ \\
\hline Primary & $8.79 \%$ \\
\hline Secondary & $19.01 \%$ \\
\hline Higher Secondary & $47.90 \%$ \\
\hline University & $16.85 \%$ \\
\hline Others & $2.99 \%$ \\
\hline \multicolumn{2}{|l|}{ Occupation } \\
\hline Unemployed & $5.75 \%$ \\
\hline Student & $41.61 \%$ \\
\hline Self-Employed & $20.84 \%$ \\
\hline Business & $11.50 \%$ \\
\hline Service Holder (Govt.) & $5.95 \%$ \\
\hline Service Holder (Private) & $7.37 \%$ \\
\hline Housewife & $6.98 \%$ \\
\hline \multicolumn{2}{|l|}{ Religion } \\
\hline Islam & $82.68 \%$ \\
\hline Hindu & $12.31 \%$ \\
\hline Buddhist & $3.32 \%$ \\
\hline Christian & $0.88 \%$ \\
\hline Other & $0.81 \%$ \\
\hline
\end{tabular}

In addition, the government can fund counselors and support groups to talk to anyone who is released from quarantine. According to the survey, $74 \%$ of respondents agreed that it is reasonable to take away some rights during an outbreak. Those who violate quarantine directives should face severe consequences such as fines or jail. $71 \%$ of respondents supported that the government should imprison them if they fail to obey quarantine orders. $82 \%$ of participants believed that going to quarantine would protect the community from becoming sick. More statistical findings from Table 3 revealed that $63 \%$ of participants agreed to use bracelets and home security cameras for people who disobey quarantine orders, $85 \%$ agreed to include a clarification of authority for quarantine, $83 \%$ agreed to pay nurses and counselors, $86 \%$ agreed to ensure food and shelter 
Table 3. Public attitudes towards quarantine during the COVID-19 outbreak

\begin{tabular}{|c|c|c|c|c|c|}
\hline & SA & SWA & $\mathbf{N}$ & SWD & SD \\
\hline Government should have the power to order people into quarantine during outbreaks. & $63 \%$ & $25 \%$ & $10 \%$ & $2 \%$ & $0 \%$ \\
\hline Quarantine is a good way to stop the spread of COVID-19 outbreak. & $63 \%$ & $25 \%$ & $10 \%$ & $2 \%$ & $0 \%$ \\
\hline $\begin{array}{l}\text { If someone is given a quarantine order by the authority, they should follow it no matter what } \\
\text { else is going on in their life at work or home. }\end{array}$ & $49 \%$ & $27 \%$ & $16 \%$ & $6 \%$ & $2 \%$ \\
\hline If I go into quarantine, my family/friends/community will be protected from becoming sick. & $58 \%$ & $24 \%$ & $13 \%$ & $3 \%$ & $1 \%$ \\
\hline People who break quarantine orders on purpose should face legal penalties like a fine or jail. & $46 \%$ & $28 \%$ & $17 \%$ & $7 \%$ & $2 \%$ \\
\hline Government should be able to lock people up if they fail to obey quarantine orders. & $43 \%$ & $28 \%$ & $16 \%$ & $9 \%$ & $4 \%$ \\
\hline $\begin{array}{l}\text { Government should use electronic bracelets and in-home surveillance cameras for people who } \\
\text { disobey quarantine orders. }\end{array}$ & $39 \%$ & $24 \%$ & $23 \%$ & $9 \%$ & $5 \%$ \\
\hline The authority needs to explain to everyone why they should be allowed to use quarantine. & $64 \%$ & $21 \%$ & $10 \%$ & $4 \%$ & $1 \%$ \\
\hline Government should pay for nurses and counselors to help people who are in quarantine. & $59 \%$ & $24 \%$ & $12 \%$ & $4 \%$ & $1 \%$ \\
\hline $\begin{array}{l}\text { Government should ensure that people have food and shelter while in quarantine, and pay for } \\
\text { it with public money if need be. }\end{array}$ & $70 \%$ & $16 \%$ & $8 \%$ & $4 \%$ & $1 \%$ \\
\hline $\begin{array}{l}\text { Government should pay for counselors and support groups so that people coming out of } \\
\text { quarantine have someone to talk to about it. }\end{array}$ & $46 \%$ & $30 \%$ & $18 \%$ & $4 \%$ & $2 \%$ \\
\hline People in quarantine should get money from the government to pay for missed time at work. & $48 \%$ & $25 \%$ & $21 \%$ & $4 \%$ & $2 \%$ \\
\hline Government should ensure that there is no discrimination in the use of quarantine. & $59 \%$ & $22 \%$ & $13 \%$ & $5 \%$ & $1 \%$ \\
\hline It is reasonable for some rights to be taken away during an infectious disease outbre & $48 \%$ & $26 \%$ & $17 \%$ & $7 \%$ & $2 \%$ \\
\hline
\end{tabular}

for people in quarantine, $73 \%$ accepted that citizens should get money from the government to compensate for lost work, and $81 \%$ responded that government should ensure that quarantine is not used discriminatorily.

It is observed that significantly different mean knowledge scores exist between age groups $(\mathrm{p}<0.01)$. The age groups between 26 and 60 had considerably higher scores than those younger and those older than them. The difference in mean knowledge scores between people living in urban areas and rural areas is very little $(25.78 \pm 7.14$ and $26.83 \pm 7.11$, respectively). It is also observed that those with higher education levels scored less than those with lower (24.06 \pm 6.21 and $30.73 \pm 6.68$, respectively). It is also observed that people who are currently earning and homemakers, retired or unemployed scored higher than students $(29.13 \pm 7.02,27.57 \pm 7.18$, and $22.59 \pm 5.47$, respectively).

\section{DISCUSSION}

Quarantine is the separation and restriction of activities for ensuring safety during a pandemic [16]. This study has found that among all the participants, a significant number of participants have agreed that quarantine is a key method for combating the COVID-19. Among them, many participants acknowledged the implementation of sanctions on people who violate quarantine laws. According to the following statistical findings, $95 \%$ in Taiwan, $76 \%$ in the USA, and $89 \%$ in Singapore, quarantine is preferable to people [17]. These results are close to the findings of this survey, which showed that $88 \%$ of the participants believed quarantine is a good way to stop the spread of the COVID19 outbreak. Furthermore, $82 \%$ accepted that quarantine will protect their family/friends/community from becoming sick.
According to the findings of this survey, $74 \%$ of respondents supported that people who violated quarantine laws should face legal penalties like fines or jail.

On a global scale, public health appears to be in a state of indecision concerning the application of quarantine and other human rights-related consequences of the outbreak. Some people think of quarantine as a sagacious health policy during epidemics [18], while others think of it as an unnecessary violation of human rights [19]. As a result, public health officials must rely on persuasion to include appropriate and explicit guidance about the intent of quarantine [20-22]. Nevertheless, quarantine plays a vital role in decreasing the transmission of contagious diseases during the COVID-19 epidemic. This survey has indicated that quarantine is a public health duty that describes both the restraint of human rights and the obligation of the public health policy within the framework of the COVID-19 outbreak.

During this survey, we faced some limitations. We only could survey eight divisions. But prospective surveys should be conducted in all 64 districts. In this survey, a major portion of the respondents was a young adult, and the number of aged participants was low. Therefore, senior participants should be provided the same priority as young participants in future research.

\section{CONCLUSIONS}

Authorities could not handle the outbreak of COVID-19 due to a lack of knowledge about this contagious disease. When a new viral disease evolves, its mode of transmission, incubation period, the causative agent remains obscured. Therefore, quarantine is the best option for protection by 
prohibiting contact between infected people and noninfected people. The current results suggest broad public support for the use of quarantine to manage COVID-19 and severe penalties for irresponsible people who violate quarantine. Our findings also indicate that individuals who the outbreak has negatively impacted should have access to psychological supports. Infectious disease has become a threat because it creates a conflict between human rights for the common benefit of society and public health ethics. Authorities and public health policymakers should introduce a comprehensive and robust support system of services and protections, inform frontline public health personnel about restrictive values' ethical usefulness, and involve the public in an open discussion to generate broad public support for the mandatory quarantine and other restrictive steps.

Author contributions: RR: designed the study and wrote the draft manuscript. AK: analyzed and interpreted the data. MM: conceived the study and carried out the revisions. RR, AM, and MK: conducted the surveys. AK, MK, and RR: helped the interpretation of the data. All authors have agreed with the results and conclusions. All authors approved the final version of the manuscript.

Funding: No funding source is reported for this study.

Acknowledgements: The authors are thankful to the members of the Community of Biotechnology for their supports during the preparation of the manuscript.

Declaration of interest: No conflict of interest is declared by authors.

\section{REFERENCES}

1. Cetron M, Simone P. Battling $21^{\text {st }}$-century scourges with a $14^{\text {th }}$-century toolbox. Emerg Infect Dis 2004;10(11):2053-4. doi:10.3201/eid1011.040797_12.

2. Wilder-Smith A, Freedman DO. Isolation, quarantine, social distancing and community containment: pivotal role for old-style public health measures in the novel coronavirus (2019-nCoV) outbreak. J Travel Med 2020;27(2):taaa020. doi: 10.1093/jtm/taaa020.

3. Hawryluck L, Gold WL, Robinson S, Pogorski S, Galea S, Styra R. SARS control and psychological effects of quarantine, Toronto, Canada. Emerg Infect Dis 2004;10(7):1206-12. doi: 10.3201/eid1007.030703.

4. Markel H, Lipman HB, Navarro JA, et al. Nonpharmaceutical interventions implemented by US cities during the 1918-1919 influenza pandemic. JAMA 2007;298(6):644-54. doi: 10.1001/jama.298.6.644.

5. Day T, Park A, Madras N, Gumel A, Wu J. When is quarantine a useful control strategy for emerging infectious diseases? Am J Epidemiol 2006;163(5):479-85. doi: 10.1093/aje/kwj056.

6. Cetron M, Landwirth J. Public health and ethical considerations in planning for quarantine. Yale J Biol Med 2005;78(5):329-34.

7. Schabas R. Severe acute respiratory syndrome: Did quarantine help? Can J Infect Dis Med Microbiol 2004;15(4):204. doi: 10.1155/2004/521892.
8. Cava MA, Fay KE, Beanlands HJ, McCay EA, Wignall R. Risk perception and compliance with quarantine during the SARS outbreak. J Nurs Scholarsh 2005;37(4):343-7. doi: 10.1111/j.1547-5069.2005.00059.x.

9. McCollum AM, Blanton JD, Holman RC, et al. Community survey after rabies outbreaks, Flagstaff, Arizona, USA. Emerg Infect Dis 2012;18(6):932-8. doi: 10.3201/eid1806.111172.

10. Kim EY, Liao Q, Yu ES, et al. Middle East respiratory syndrome in South Korea during 2015: Risk-related perceptions and quarantine attitudes. Am J Infect Control 2016;44(11):1414-6. doi: 10.1016/j.ajic.2016. 03.014 .

11. Jacobs LA. Rights and quarantine during the SARS global health crisis: Differentiated legal consciousness in Hong Kong, Shanghai, and Toronto. Law Soc Rev 2007;41(3):511-52. doi:10.1111/j.1540-5893.2007. 00313.x.

12. Habib WB, Sujan MA. Coronavirus in Bangladesh: First death amid sloppy response. The Daily Star. Available at: https://www.thedailystar.net/frontpage/news/coronavir us-bangladesh-first-death-amid-slack-readiness1882642

13. World Health Organization. Coronavirus disease (COVID-2019) Bangladesh situation reports. WHO. Available at: https://www.who.int/docs/defaultsource/searo/bangladesh/covid-19-who-bangladeshsituation-reports/who-ban-covid-19-sitrep07.pdf?.sfvrsn=8ebbdd17_6

14. Nowshin N. Can quarantine be a solution in a country like Bangladesh? The Daily Star. Available at: https://www.thedailystar.net/opinion/news/canquarantine-be-solution-country-bangladesh-1884067

15. Masum O. How effective home quarantine is for Bangladesh to fight coronavirus. Bdnews24.com. Available at: https://bdnews24.com/health/2020/03/16/ how-effective-home-quarantine-is-for-bangladesh-tofight-coronavirus

16. Gostin L. Public health strategies for pandemic influenza: ethics and the law. JAMA 2006;295(14):1700-4. doi: 10.1001/jama.295.14.1700.

17. Blendon RJ, DesRoches CM, Cetron MS, Benson JM, Meinhardt T, Pollard W. Attitudes toward the use of quarantine in a public health emergency in four countries. Health Aff (Millwood) 2006;25(2):w15-w25. doi: 10.1377/hlthaff.25.w15.

18. Gostin LO, Bayer R, Fairchild AL. Ethical and legal challenges posed by severe acute respiratory syndrome: Implications for the control of severe infectious disease threats. JAMA 2003;290(24):3229-37. doi: 10.1001/ jama.290.24.3229.

19. Tasioulas J, Vayena E. Public health and human rights. JAMA 2016;316(1):103-4. doi: 10.1001/jama.2016. 5244 
20. Digiovanni C, Conley J, Chiu D, Zaborski J. Factors influencing compliance with quarantine in Toronto during the 2003 SARS outbreak. Biosecur Bioterror 2004;2(4):265-72. doi: 10.1089/bsp.2004.2.265.

21. Braunack-Mayer A, Tooher R, Collins JE, Street JM, Marshall $\mathrm{H}$. Understanding the school community's response to school closures during the H1N1 2009 influenza pandemic. BMC Public Health 2013;13:344. doi: 10.1186/1471-2458-13-344.
22. Cava MA, Fay KE, Beanlands HJ, McCay EA, Wignall R. The experience of quarantine for individuals affected by SARS in Toronto. Public Health Nurs 2005;22(5):398406. doi: 10.1111/j.0737-1209.2005.220504.x. 